\title{
A Quantitative Assessment of the Influence of Permanent Kinks on the Mixing Behavior of Phospholipids in Cholesterol-Rich Bilayers
}

\author{
Bingwen Jing, Nobuya Tokutake, Donald H. Mccullough, and Steven L. Regen \\ Department of Chemistry, Lehigh University, Bethlehem, Pennsylvania 18015
}

Supporting Information

Materials. Unless stated otherwise, all reagents and chemicals were obtained from commercial sources and used without futher purification. Dithiobis[succinimidyl proprionate] (Pierce Chemical Co), tris(2-carboxyethyl)phosphine hydrochloride [TCEP] (Fluka Chemical Co), 1,8-dizazbicyclo[5.4.0]undec-7-ene (DBU) (Aldrich Chemical Co.), 1-palmitoyl-2-hydroxy-sn-glycero-3-phosphoethanolamine (Avanti Polar Lipids), aqueous $\mathrm{NH}_{4} \mathrm{OH}\left(30 \% \mathrm{NH}_{3}\right)$ (Aldrich Chemical Co.) were used as obtained. House-deionized water was purified using a Millipore Milli-Q-filtering system containing one carbon and two ion-exchange stages. All chromatography solvents and materials and (i.e., silica gel and reverse phase $\mathrm{C} 18$ preparative thin layer chromatography plates) were obtained from EM Science.

cis-9,10-Methyleneoctadecanoic Acid (Dihydrosterculic Acid, DS). Procedures that were used for the synthesis of dihydrosterculic acid (DS) were similar to those previously described [Charette, A. B.; Sebastien, F.; Martel, J.; Wilb, N. Angew. Chem., Int. Ed., 2000, 39, 4539]. To a solution of $2.76 \mathrm{~g}$ (14 mmol) of 2,4,6trichlorophenol in $50 \mathrm{~mL}$ of anhydrous methylene chloride, which was maintained at $40^{\circ} \mathrm{C}$, was added $14 \mathrm{~mL}(14 \mathrm{mmol})$ of a $1 \mathrm{M}$ hexane solution of diethylzinc. After stirring for $15 \mathrm{~min}$ at $-40^{\circ} \mathrm{C}, 1.13 \mathrm{~mL}(14 \mathrm{mmol})$ of $\mathrm{CH}_{2} \mathrm{I}_{2}$ was added. The solution was then stirred an $15 \mathrm{~min}$ at $-40^{\circ} \mathrm{C}$, and $1.00 \mathrm{~g}(3.5 \mathrm{mmol})$ of oleic acid was added. After stirring overnight at room temperature, the mixture was washed with $100 \mathrm{~mL}$ of $10 \%$ $\mathrm{HCl}$. The aqueous phase was then extracted with $3 \times 50 \mathrm{~mL}$ of chloroform and the chloroform extract combined with the organic layer of the product mixture. Subsequent drying over anhydrous $\mathrm{MgSO}_{4}$, followed by removal of solvent under reduced pressure, and chromatographic purification of the residue [silica gel, $\left(\mathrm{CHCl}_{3} / \mathrm{CH}_{3} \mathrm{OH},(10: 1, \mathrm{v} / \mathrm{v})\right.$ ] afforded $574 \mathrm{mg}(52 \%)$ of cis-9,10-methyleneoctadecanoic acid having ${ }^{1} \mathrm{H} \mathrm{NMR}\left(\mathrm{CDCl}_{3}\right.$, $500 \mathrm{MHz}, \mathrm{rt}) \delta \mathrm{ppm}:-0.36(\mathrm{q}, 1 \mathrm{H}), 0.54(\mathrm{~m}, 1 \mathrm{H}), 0.63(\mathrm{br} \mathrm{s}, 2 \mathrm{H}), 0.86(\mathrm{t}, 3 \mathrm{H}), 1.11(\mathrm{~m}, 2$ $\mathrm{H}), 1.30(\mathrm{~m}, 22 \mathrm{H}), 1.62$ (pent, $2 \mathrm{H}), 2.22(\mathrm{t}, 2 \mathrm{H})$. 
trans-9,10-Methyleneoctadecanoic Acid. Procedures that were used were similar to those employed for the synthesis of cis-9,10-methyleneoctadecanoic acid, except that elaidic acid was used in place of oleic acid. The isolated yield of product (59\%) had ${ }^{1} \mathrm{H} \mathrm{NMR}\left(\mathrm{CDCl}_{3}, 360 \mathrm{MHz}, \mathrm{rt}\right) \delta \mathrm{ppm}$ : 0.11(t, $\left.2 \mathrm{H}\right), 0.33$ (hept, $\left.2 \mathrm{H}\right), 0.86(\mathrm{t}, 3$ $\mathrm{H}), 1.04-1.35(\mathrm{~m}, 24 \mathrm{H}), 1.61$ (pent, $2 \mathrm{H}), 2.32(\mathrm{t}, 2 \mathrm{H})$.

Di-[1-palmitoyl-sn-glycero-3-phosphoethanol-(3'-thio)propionamide] (4). To a solution made from $200 \mathrm{mg}(0.441 \mathrm{mmol})$ of 1-palmitoyl-2-hydroxy-sn-glycero-3phosphoethanolamine, $184 \mathrm{I} \mu(1.32 \mathrm{mmol})$ of triethylamine, and $4 \mathrm{~mL}$ of chloroform/methanol (3/1, v/v), was added $89 \mathrm{mg}(0.22 \mathrm{mmol})$ of dithiobis[succinimidyl proprionate]. The resulting mixture was stirred at room temperature for $5 \mathrm{~h}$. Additional dithiobis[succinimidyl proprionate] was then added at a rate of $10 \mathrm{mg} / \mathrm{h}$, until all of the starting phosphoethanolamine had reacted (TLC), which typically required $5 \mathrm{~h}$. Removal of solvent under reduced pressure, followed by prepartive TLC [silica gel, $\mathrm{CHCl}_{3} / \mathrm{CH}_{3} \mathrm{OH} / \mathrm{NH}_{4} \mathrm{OH}(65 / 25 / 4, \mathrm{v} / \mathrm{v} / \mathrm{v})$ afforded $110 \mathrm{mg}(46 \%)$ of 4 having $\mathrm{R}_{\mathrm{f}} 0.22$ and ${ }^{1} \mathrm{H} \mathrm{NMR}\left(\mathrm{CDCl}_{3}, 500 \mathrm{MHz}, \mathrm{rt}\right) \delta \mathrm{ppm}: 0.84(\mathrm{t}, 6 \mathrm{H}), 1.22(\mathrm{~m}, 48 \mathrm{H}), 1.56(\mathrm{~m}, 4 \mathrm{H}), 2.30(\mathrm{t}$, $4 \mathrm{H}), 2.60(\mathrm{t}, 4 \mathrm{H}), 2.92(\mathrm{t}, 4 \mathrm{H}), 3.39(\mathrm{t}, 4 \mathrm{H}), 3.80-3.96(\mathrm{~m}, 10 \mathrm{H}), 4.11(\mathrm{~m}, 4 \mathrm{H})$.

Di-[1-Palmitoyl,2-cis-9-octadecenoyl-sn-glycero-3-phosphoethanol-(3'thio)propionamide] $\{\mathbf{1}, \mathbf{1}\}$. To a solution made from $124 \mathrm{mg}(0.4 \mathrm{mmol})$ of cis-9octadecenoic acid and $2 \mathrm{~mL}$ of chloroforom was added $33 \mathrm{mg}(0.48 \mathrm{mmol})$ of imidazole and $99 \mathrm{mg}(0.48 \mathrm{mmol})$ of DCC. The mixture was stirred at room temperature for $5 \mathrm{~h}$, followed by filtration to remove the insoluble urea. The filtrate was then concentrated under reduced pressure and the residue dried overnight in a freeze dryer. The residue was then dissolved in a solution made from $2 \mathrm{~mL}$ of chloroform, $54 \mathrm{mg}(0.05 \mathrm{mmol})$ of 4 , and $100 \mu \mathrm{L}$ of DBU. After stirring overnight at room temperature, the product mixture was washed with $30 \mathrm{~mL}$ of $1 \mathrm{M} \mathrm{HCl}$, followed by extraction with $3 \times 20 \mathrm{~mL}$ of chloroform. The combined organic solution and organic extract was concentrated under reduced pressure and the residue purified by preparative TLC [silica gel, $\mathrm{CHCl}_{3} / \mathrm{CH}_{3} \mathrm{OH} / \mathrm{H}_{2} \mathrm{O}$ $(30 / 10 / 1, v / v / v)]$ to give a crude product having $\mathrm{R}_{\mathrm{f}} 0.38$. This product was removed from the silica gel using $50 \mathrm{~mL}$ of $\mathrm{CHCl}_{3} / \mathrm{CH}_{3} \mathrm{OH} / \mathrm{H}_{2} \mathrm{O}(65 / 25 / 4$, v/v/v). A second preparative TLC [reverse phase, C18-modified silica, $\mathrm{CHCl}_{3} / \mathrm{CH}_{3} \mathrm{OH} / \mathrm{NH}_{4} \mathrm{OH}(35 / 45 / 10$, v/v/v)] afforded $59 \mathrm{mg}(72 \%)$ of the desired $\{\mathbf{1}, \mathbf{1}\}$ having $\mathrm{R}_{\mathrm{f}} 0.44$ and ${ }^{1} \mathrm{H}$ NMR $\left(\mathrm{CDCl}_{3}, 500\right.$ MHz, rt) $\delta$ ppm: $\quad-0.35(\mathrm{q}, 2 \mathrm{H}), 0.56(\mathrm{~m}, 2 \mathrm{H}), 0.63(\mathrm{~m}, 4 \mathrm{H}), 0.86(\mathrm{t}, 12 \mathrm{H}), 1.10-1.40(\mathrm{~m}$, $96 \mathrm{H}), 1.58(\mathrm{~m}, 8 \mathrm{H}), 2.27(\mathrm{~m}, 8 \mathrm{H}), 2.61(\mathrm{t}, 4 \mathrm{H}), 2.97(\mathrm{t}, 4 \mathrm{H}), 3.43(\mathrm{~m}, 4 \mathrm{H}), 3.89(\mathrm{~m}, 8 \mathrm{H})$, 4.13(m, $2 \mathrm{H}), 4.37(\mathrm{~d}, 2 \mathrm{H}), 5.20(\mathrm{~s}, 2 \mathrm{H}), 7.53(\mathrm{br} \mathrm{s}, 2 \mathrm{H})$. HRMS for $\left(\mathrm{C}_{86} \mathrm{H}_{161} \mathrm{O}_{18} \mathrm{~N}_{2} \mathrm{P}_{2} \mathrm{~S}_{2}\right)$ MALDI [M $\left.{ }^{2-}+\mathrm{H}^{+}\right]^{-}$Calcd.: 1636.0656. Found: 1636.0551

1,2-Dimyristoyl-sn-glycero-3-phosphoethanol-(3'-thio)propionamide-[1palmitoyl,2-cis-9-octadecenoyl-sn-glycero-3-phosphoethanol-(3'-thio)propionamide] $\{\mathbf{1 , 3 a}\}$. To a solution that was prepared from $10 \mathrm{mg}(0.035 \mathrm{mmol})$ of TCEP and 0.100 
$\mathrm{mL}$ of water was added $0.25 \mathrm{~mL}$ of chloroform containing $17 \mathrm{mg}(0.01 \mathrm{mmol})$ of $\{\mathbf{1 , 1}\}$., followed by addition of $0.35 \mathrm{~mL}$ of methanol. After stirring for $2 \mathrm{~h}$ at room temperature,the solution was concentrated under reduced pressure and subjected to preparative TLC [silica gel, $\mathrm{CHCl}_{3} / \mathrm{CH}_{3} \mathrm{OH} / \mathrm{H}_{2} \mathrm{O}(65 / 25 / 4$, v/v/v)] to give the corresponding thiol monomer having $\mathrm{R}_{\mathrm{f}}$ 0.45. This monomer was then dissolved in $5 \mathrm{~mL}$ of chloroform and the resulting solution added, dropwise, to a solution made from $5 \mathrm{~mL}$ of chloroform and $20 \mathrm{mg}(0.026 \mathrm{mmol})$ of 1,2-dimyristoyl-sn-glycero-3-phosphoethanol(2' pyridyldithio) propionamide (6). The reaction mixture was stirred overnight at room temperature, and then concentrated under reduced pressure. The desired heterodimer, $\{\mathbf{1 , 3 a}\}$, was obtained by three successive, preparative TLC purifications: (1) [silica gel, $\mathrm{CHCl}_{3} / \mathrm{CH}_{3} \mathrm{OH} / \mathrm{H}_{2} \mathrm{O}(30 / 10 / 4, \mathrm{v} / \mathrm{v} / \mathrm{v}), \mathrm{R}_{\mathrm{f}}$ 0.40], (2) [reverse phase, C18-modified silica, $\left.\mathrm{CHCl}_{3} / \mathrm{CH}_{3} \mathrm{OH} / \mathrm{NH}_{4} \mathrm{OH}\right)(40 / 40 / 10, \mathrm{v} / \mathrm{v} / \mathrm{v}), \mathrm{R}_{\mathrm{f}} 0.50$ ], and (3) [silica gel, $\left.\mathrm{CHCl}_{3} / \mathrm{CH}_{3} \mathrm{OH} / \mathrm{H}_{2} \mathrm{O}(65 / 25 / 4, \mathrm{v} / \mathrm{v} / \mathrm{v}), \mathrm{R}_{\mathrm{f}} 0.49\right]$ to give $20 \mathrm{mg}(64 \%)$ of product having ${ }^{1} \mathrm{H}$ NMR $\left(\mathrm{CDCl}_{3}, 360 \mathrm{MHz}, \mathrm{rt}\right) \delta \mathrm{ppm}:-0.36(\mathrm{q}, 1 \mathrm{H}), 0.55(\mathrm{~m}, 1 \mathrm{H}), 0.61(\mathrm{~d}, 2 \mathrm{H}), 0.86(\mathrm{t}, 12$ $\mathrm{H}), 1.00-1.40(\mathrm{~m}, 88 \mathrm{H}), 1.55(\mathrm{~m}, 8 \mathrm{H}), 2.27(\mathrm{~m}, 8 \mathrm{H}), 2.61(\mathrm{~m}, 4 \mathrm{H}), 2.97(\mathrm{~m}, 4 \mathrm{H}), 3.43(\mathrm{~s}, 4$ $\mathrm{H}), 3.87(\mathrm{~m}, 8 \mathrm{H}), 4.13(\mathrm{~m}, 2 \mathrm{H}), 4.37(\mathrm{~d}, 2 \mathrm{H})$, 5.19(s, $2 \mathrm{H}), 7.70(\mathrm{~s}, 2 \mathrm{H})$. HRMS for $\left(\mathrm{C}_{79} \mathrm{H}_{149} \mathrm{O}_{18} \mathrm{~N}_{2} \mathrm{P}_{2} \mathrm{~S}_{2}\right)^{+}$MALDI $\left[\mathrm{M}^{2-}+\mathrm{H}^{+}\right]^{-}$Calcd.: 1539.9717. Found: 1539.9736.

Di-[1-Palmitoyl,2-trans-9-octadecenoyl-sn-glycero-3-phosphoethanol-(3'-

thio)propionamide] $\{\mathbf{2 , 2}\}$. A mixture of $233 \mathrm{mg}(0.78 \mathrm{mmol})$ of trans-9-octadecenoic acid, $64 \mathrm{mg}(0.943 \mathrm{mmol})$ of imidazole and $195 \mathrm{mg}(0.043 \mathrm{mmol})$ of DCC in $3 \mathrm{~mL}$ of chloroform was stirred at room temperature for $6 \mathrm{~h}$. The insoluble urea that formed was removed by filtration, and the filtrate containing the activated form of the acid was concentrated under reduced pressure and dried over night in a freeze dryer. The activated acid was then dissolved in $1 \mathrm{~mL}$ of chloroform and added to a solution that was

made from $170 \mathrm{mg}(0.157 \mathrm{mmol})$ of $4,188 \mu \mathrm{L}(1.26 \mathrm{mmol})$ of DBU and $3 \mathrm{~mL}$ of chloroform. After stirring overnight at room temperature, the product mixture was poured into $30 \mathrm{~mL}$ of $1 \mathrm{M} \mathrm{HCl}$, followed by extraction with $3 \times 30 \mathrm{~mL}$ of chloroform. The combined organic extract and organic phase of the product mixture was concentrated under reduced pressure and $216 \mathrm{mg}(84 \%)$ of the crude homodimer, $\{\mathbf{2}, \mathbf{2}\}$, containing a small impurity was obtained by two successive, preparative TLC purifications: (1) [silica gel, $\mathrm{CHCl}_{3} / \mathrm{CH}_{3} \mathrm{OH} / \mathrm{NH}_{4} \mathrm{OH}\left(65 / 25 / 4\right.$, v/v/v), $\mathrm{R}_{\mathrm{f}} 0.41$ ]; (2) [silica gel, $\mathrm{CHCl}_{3} / \mathrm{CH}_{3} \mathrm{OH} / \mathrm{H}_{2} \mathrm{O}$ $(30 / 10 / 1, v / v / v)], R_{\mathrm{f}} 0.38$. Taking $35 \mathrm{mg}$ of crude $\{\mathbf{2}, \mathbf{2}\}$ for further purification by preparative reverse phase TLC, [C18-modified silica, $\mathrm{CHCl}_{3} / \mathrm{CH}_{3} \mathrm{OH} / \mathrm{NH}_{4} \mathrm{OH}(30 / 50 / 20$, $\mathrm{v} / \mathrm{v} / \mathrm{v})$ ] afforded a product having $\mathrm{R}_{\mathrm{f}}$ 0.11. One final preparative TLC [silica gel, $\left.\mathrm{CHCl}_{3} / \mathrm{CH}_{3} \mathrm{OH} / \mathrm{H}_{2} \mathrm{O}(65 / 25 / 4, \mathrm{v} / \mathrm{v} / \mathrm{v})\right]$ afforded $24 \mathrm{mg}$ of pure homodimer $\{\mathbf{2}, 2\}$ having $\mathrm{R}_{\mathrm{f}}$ 0.48 and ${ }^{1} \mathrm{H}$ NMR $\left(\mathrm{CDCl}_{3}, 360 \mathrm{MHz}, \mathrm{rt}\right) \delta \mathrm{ppm}: 0.13(\mathrm{~m}, 4 \mathrm{H}), 0.34(\mathrm{~m}, 4 \mathrm{H}), 0.87(\mathrm{t}, 12$ $\mathrm{H}), 1.10-1.40(\mathrm{~m}, 96 \mathrm{H}), 1.57(\mathrm{~m}, 8 \mathrm{H}), 2.27(\mathrm{~m}, 8 \mathrm{H}), 2.63(\mathrm{t}, 4 \mathrm{H}), 2.98(\mathrm{t}, 4 \mathrm{H}), 3.45(\mathrm{~m}, 4$ $\mathrm{H}), 3.89(\mathrm{~m}, 8 \mathrm{H}), 4.15(\mathrm{~m}, 2 \mathrm{H}), 4.38(\mathrm{~d}, 2 \mathrm{H}), 5.19(\mathrm{~s}, 2 \mathrm{H}), 7.55(\mathrm{~s}, 2 \mathrm{H})$. HRMS for $\left(\mathrm{C}_{86} \mathrm{H}_{161} \mathrm{O}_{18} \mathrm{~N}_{2} \mathrm{P}_{2} \mathrm{~S}_{2}\right)^{+}$MALDI $\left[\mathrm{M}^{2-}+\mathrm{H}^{+}\right]^{-}$Calcd.: 1636.0656. Found: 1636.0683. 
1,2-Dimyristoyl-sn-glycero-3-phosphoethanol-(3'-thio)propionamide-[1palmitoyl,2-trans-9-octadecenoyl-sn-glycero-3-phosphoethanol-(3'-

thio)propionamide $\{\mathbf{2}, \mathbf{3 a}\}$. To a solution that was made from $33 \mathrm{mg}(0.02 \mathrm{mmol})$ of $\{\mathbf{2 , 2}\}$ and $2 \mathrm{~mL}$ of chloroform was added a solution made from $29 \mathrm{mg}(0.1 \mathrm{mmol})$ of TCEP plus $0.100 \mathrm{~mL}$ of water and $1 \mathrm{~mL}$ of methanol. After the reaction mixture was stirred for $2 \mathrm{~h}$ at room temperature, removal of solvent under reduced pressure and purification by preparative TLC [silica gel, $\mathrm{CHCl}_{3} / \mathrm{CH}_{3} \mathrm{OH} / \mathrm{H}_{2} \mathrm{O}(65 / 25 / 4$, v/v/v)] afforded the corresponding thiol having $\mathrm{R}_{\mathrm{f}} 0.45$. To a solution of this thiol monomer in $20 \mathrm{~mL}$ of chloroform was added, dropwise, a solution made from $34 \mathrm{mg}(0.045 \mathrm{mmol})$ of 1,2-dimyristoyl-sn-glycero-3-phosphoethanol-(2'-pyridyldithio)propionamide (6) in 20 $\mathrm{mL}$ of chloroform. After stirring overnight at room temperature, removal of solvent under reduced pressure, followed by preparative TLC purification (twice) [silica gel, $\left.\mathrm{CHCl}_{3} / \mathrm{CH}_{3} \mathrm{OH} / \mathrm{H}_{2} \mathrm{O}(65 / 25 / 4, \mathrm{v} / \mathrm{v} / \mathrm{v})\right]$ afforded $49 \mathrm{mg}(84 \%)$ of the desired heterodimer, $\{\mathbf{2 , 3}\}$, having $\mathrm{R}_{\mathrm{f}} 0.42$ and ${ }^{1} \mathrm{H} \mathrm{NMR}\left(\mathrm{CDCl}_{3}, 360 \mathrm{MHz}, \mathrm{rt}\right) \delta \mathrm{ppm}: 0.11(\mathrm{~m}, 2 \mathrm{H}), 0.33(\mathrm{~m}, 2$ H), 0.86(t, $12 \mathrm{H}), 1.10-1.40(\mathrm{~m}, 88 \mathrm{H}), 1.55(\mathrm{~m}, 8 \mathrm{H}), 2.28(\mathrm{~m}, 8 \mathrm{H}), 2.60(\mathrm{~m}, 4 \mathrm{H}), 2.97(\mathrm{~m}$, $4 \mathrm{H}), 3.43(\mathrm{~m}, 4 \mathrm{H}), 3.85(\mathrm{~m}, 8 \mathrm{H}), 4.12(\mathrm{~m}, 2 \mathrm{H}), 4.38(\mathrm{~d}, 2 \mathrm{H}), 5.17(\mathrm{~s}, 2 \mathrm{H}), 7.70$ (br s, 2 $\mathrm{H})$. HRMS for $\left(\mathrm{C}_{79} \mathrm{H}_{149} \mathrm{O}_{18} \mathrm{~N}_{2} \mathrm{P}_{2} \mathrm{~S}_{2}\right)$ MALDI $\left[\mathrm{M}^{2-}+\mathrm{H}^{+}\right]^{-}$Calcd.: 1539.9717. Found: 1539.9781.

1,2-Dipalmitoyl-sn-glycero-3-phosphoethanol-(3'-thio)propionamide-[1-palmitoyl,2cis-9-octadecenoyl-sn-glycero-3-phosphoethanol-(3'-thio)propionamide] $\quad\{\mathbf{1}, \mathbf{3 b}\}$. Procedures that were used to prepare $\{\mathbf{1}, \mathbf{3 b}\}$ were similar to those used for the preparation of $\{\mathbf{1}, \mathbf{3 a}\}$. The resulting phospholipid was obtained in $61 \%$ isolated yield, having $\mathrm{R}_{\mathrm{f}} 0.50$ [silica gel, $\mathrm{CHCl}_{3} / \mathrm{CH}_{3} \mathrm{OH} / \mathrm{H}_{2} \mathrm{O}(65 / 25 / 4, \mathrm{v} / \mathrm{v} / \mathrm{v})$ ], and ${ }^{1} \mathrm{H} \mathrm{NMR}\left(\mathrm{CDCl}_{3}\right.$, $500 \mathrm{MHz}, \mathrm{rt}): 0.36(\mathrm{q}, 1 \mathrm{H}), 0.55(\mathrm{~m}, 1 \mathrm{H}), 0.62(\mathrm{~m}, 2 \mathrm{H}), 0.86(\mathrm{t}, 12 \mathrm{H}), 1.10-1.40(\mathrm{~m}, 96$ $\mathrm{H}), 1.55(\mathrm{~m}, 8 \mathrm{H}), 2.28(\mathrm{~m}, 8 \mathrm{H}), 2.61(\mathrm{t}, 4 \mathrm{H}), 2.97(\mathrm{t}, 4 \mathrm{H}), 3.43(\mathrm{~m}, 4 \mathrm{H}), 3.87(\mathrm{~m}, 8 \mathrm{H})$, 4.13(m, $2 \mathrm{H}), 4.37(\mathrm{~m}, 2 \mathrm{H}), 5.18(\mathrm{~s}, 2 \mathrm{H}), 7.70(\mathrm{br} \mathrm{s}, 2 \mathrm{H})$. Calcd for: $\mathrm{C}_{83} \mathrm{H}_{158} \mathrm{~N}_{2} \mathrm{O}_{18} \mathrm{P}_{2} \mathrm{~S}_{2}$ MALDI $\left[\mathrm{M}^{2-}+\mathrm{H}^{+}\right]^{-}$1596. Found: 1596.

1,2-Dipalmitoyl-sn-glycero-3-phosphoethanol-(3'-thio)propionamide-[1-palmitoyl,2trans-9-octadecenoyl-sn-glycero-3-phosphoethanol-(3'-thio)propionamide] $\{2,3 \mathbf{b}\}$. Procedures that were used to prepare $\{\mathbf{2}, \mathbf{3 b}\}$ were similar to those used for the preparation of $\{\mathbf{2}, \mathbf{3 a}\}$. The resulting phospholipid was obtained in $69 \%$ isolated yield, having $\mathrm{R}_{\mathrm{f}} 0.50$ [silica gel, $\mathrm{CHCl}_{3} / \mathrm{CH}_{3} \mathrm{OH} / \mathrm{H}_{2} \mathrm{O}\left(65 / 25 / 4\right.$, v/v/v), ] and ${ }^{1} \mathrm{H} \mathrm{NMR}\left(\mathrm{CDCl}_{3}\right.$, $500 \mathrm{MHz}$, rt $) 0.11(\mathrm{~m}, 2 \mathrm{H}), 0.33(\mathrm{~m}, 2 \mathrm{H}), 0.85(\mathrm{t}, 12 \mathrm{H}), 1.10-1.40(\mathrm{~m}, 88 \mathrm{H}), 1.55(\mathrm{~m}, 8$ $\mathrm{H}), 2.28(\mathrm{~m}, 8 \mathrm{H}), 2.60(\mathrm{~m}, 4 \mathrm{H}), 2.97(\mathrm{~m}, 4 \mathrm{H}), 3.43(\mathrm{~m}, 4 \mathrm{H}), 3.87(\mathrm{~m}, 8 \mathrm{H}), 4.13(\mathrm{~m}, 2 \mathrm{H})$, 4.38(d, $2 \mathrm{H}), 5.18(\mathrm{~s}, 2 \mathrm{H}), 7.71$ (br s, $2 \mathrm{H})$. Calcd for: $\mathrm{C}_{83} \mathrm{H}_{158} \mathrm{~N}_{2} \mathrm{O}_{18} \mathrm{P}_{2} \mathrm{~S}_{2}$ MALDI [M ${ }^{2-}$ $\left.+\mathrm{H}^{+}\right]^{-}$1596. Found: 1596 .

Nearest-Neighbor Recognition Measurements. In a typical liposome preparation, a test tube was charged with a chloroform solution that contained $0.3 \mu \mathrm{mol}$ of $\{\mathbf{1}, \mathbf{1}\}, 0.3 \mu \mathrm{mol}$ of $\{\mathbf{2}, \mathbf{2}\}$, and $0.48 \mu \mathrm{mol}$ of cholesterol (29\% cholesterol). The chloroform was then evaporated by passing a stream of argon over the solution. The lipid mixture was then dissolved in $100 \mu \mathrm{L}$ of chloroform and diluted with $270 \mu \mathrm{L}$ of 
diisopropyl ether. Subsequent addition of $35 \mu \mathrm{L}$ of $3.3 \mathrm{mM}$ tris-HCl buffer ( $3.3 \mathrm{mM}$ tris$\mathrm{HCl}, 50 \mathrm{mM} \mathrm{NaCl}, 0.67 \mathrm{mM} \mathrm{NaN}_{3}$ and $0.33 \mathrm{mM}$ EDTA, pH 7.4) produced an emulsion.

After the emulsion was sonicated for $3 \mathrm{~min}$, using a mild (bath-type) sonicator, the organic phase was removed by gentle evaporation at $60{ }^{\circ} \mathrm{C}$, resulting in a white gel at the bottom of the test tube. The gel was then collapsed by vigorous vortex mixing for 15-45 min, and $2.0 \mathrm{~mL}$ of additional $10 \mathrm{mM}$ tris- $\mathrm{HCl}$ buffer $(10 \mathrm{mM}$ tris- $\mathrm{HCl}, 150 \mathrm{mM} \mathrm{NaCl}, 2$ $\mathrm{mM} \mathrm{NaN}_{3}$ and $1 \mathrm{mM}$ EDTA, pH 7.4) was added dropwise with vortex mixing. The dispersion was then degassed with an aspirator for $5 \mathrm{~min}$, and the residual traces of organic solvent removed by dialysis (Spectra/Por Membrane, MWCO 6000-8000) under an argon atmosphere, using two $200 \mathrm{~mL}$ portions of degassed $10 \mathrm{mM}$ tris- $\mathrm{HCl}$ buffer, $\mathrm{pH}$ 7.4) over the course of $18 \mathrm{~h}$. Large unilamellar vesicles formed under these conditions were typically $1000 \mathrm{~nm}$ in diameter (dynamic light scattering).

Thiolate-disulfide interchange reactions were initiated, after the dispersions had equilibrated at the desired temperature, by increasing the $\mathrm{pH}$ to 8.5 (addition of ca. $10 \mu \mathrm{L}$ of $1.0 \mathrm{M} \mathrm{NaOH}$ ) and injecting $54 \mu \mathrm{L}$ of a tris-buffer solution of $15.1 \mathrm{mM}$ threodithiothreitol $(0.82 \mu \mathrm{mol})$ and $24 \mu \mathrm{L}$ of a tris-buffer solution of $0.42 \mu \mathrm{M}$ monensin $(10.2$ pmol) with brief vortex mixing. All dispersions were maintained under an argon atmosphere throughout the course of the interchange reactions at $30^{\circ} \mathrm{C}$. Aliquots $(0.30$ $\mathrm{mL}$ ) were withdrawn as a function of time and quenched with $80 \mu \mathrm{L}$ of $30 \mathrm{mM} \mathrm{HCl}$ (final $\mathrm{pH}$ 5.0). After removal of water under reduced pressure, the residue was triturated with $2 \mathrm{~mL}$ of chloroform and centrifuged. The chloroform layer was then removed under reduced pressure to yield a clear film, which was, subsequently, dissolved in $10 \mu \mathrm{L}$ of chloroform and $90 \mu \mathrm{L}$ of the mobile phase that was used for HPLC analysis. Under the conditions used, the extent of reduction of the lipid dimers to thiol monomers by dithiothreitol was less than $10 \%$. All exchange reactions that were carried out at $30.5^{\circ} \mathrm{C}$ reached an equilibrium point after ca. $2 \mathrm{~h}$.

Analysis of Dimer Distributions by High-Performance Liquid Chromatography. Mixtures of lipid dimers were analyzed by HPLC using a Beckman Ultrasphere C18 reverse phase column $(4.6 \times 250 \mathrm{~mm}, 5 \mu \mathrm{m}$ particle size $)$. The flow rate was $0.9 \mathrm{~mL} / \mathrm{min}$, and the column temperature was maintained at $31.0{ }^{\circ} \mathrm{C}$. Peaks were monitored at $205 \mathrm{~nm}$ by use of a Waters 996 photodiode array detector. Data were collected and processed using a Millennium workstation (Waters Corp.). The mobile phase that was used in these analyses was composed of $10 \mathrm{mM}$ tetrabutylammonium acetate (TBA) in denatured ethanol/water/hexane $(82 / 12 / 6, \mathrm{v} / \mathrm{v} / \mathrm{v})$. 


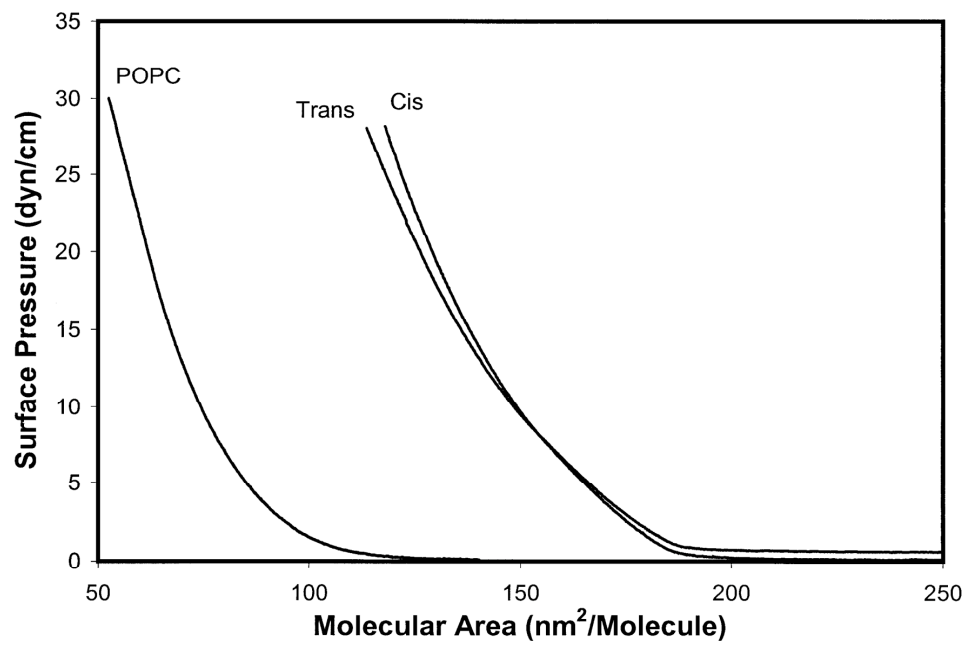

Figure 1. Surface pressure-area isotherms for POPC, "Cis" $\{\mathbf{1}, \mathbf{1}\}$ and "Trans" $\{\mathbf{2}, \mathbf{2}\}$ over a pure water subphase at $25^{\circ} \mathrm{C}$.

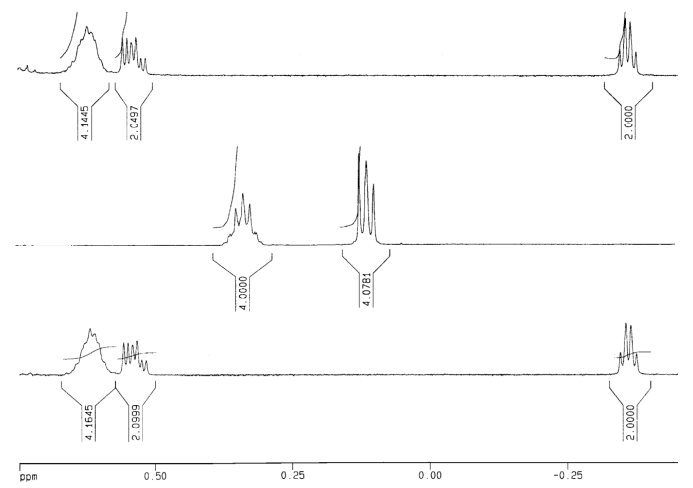

Figure 2. ${ }^{1} \mathrm{H}$ NMR spectra of the cyclopropyl region of $\{\mathbf{1 , 1}\}$ (lower spectrum), $\{\mathbf{2 , 2}\}$ (middle spectrum), and phospholipids isolated from a NNR experiment involving $\mathbf{1}$ and $\mathbf{3 a}$ after dimer equilibrium was reached (upper spectrum). 